\title{
RELIABILITY EVALUATION OF NETWORKS WITH IMPERFECT AND REPAIRABLE LINKS AND NODES
}

\section{NIEZAWODNOŚĆ SIECI Z USZKADZAJĄCYMI SIĘ I ODNAWIANYMI POŁĄCZENIAMI ORAZ WĘZŁAMI*}

\begin{abstract}
The paper presents the method for determining the reliability of a network whose elements (links and nodes) are imperfect (can fail) and repairable. The presented method uses the factoring algorithm, proposed $\pi$ method and computer simulation. The factoring algorithm is used to obtain a formula for accurate computation of network reliability as a probability of connectedness among the specified set of nodes $K\left(R_{N(K)}\right)$. The reliability calculated in this way relates to cases when only links can fail and are unrepairable. In order to calculate the reliability of a network with repairable links and nodes, we introduced quasi-failures of links which occur as a result of failures of adjacent nodes - the $\pi$ method. The developed method allows accounting for the repair of all the network elements after failure, as well as choosing the set of nodes $\left(N_{f}\right)$ which can fail independently. In addition, the probability distributions of failure time of freely specified sets of nodes and links can be different. A simulation computational model was developed for the method which allows for determining the reliability $\left(R_{N(K)}(t)\right)$ of a network with repairable links and nodes. Examples of numerical calculations were performed according to the developed model and the results are presented.
\end{abstract}

Keywords: network reliability, factoring algorithm, imperfect nodes, imperfect links, repairable elements, $\pi$ method, simulation

\begin{abstract}
W opracowaniu przedstawiono metodę wyznaczania niezawodności sieci, w których elementy (połaczenia $i$ węzty) moga się uszkadzać i sq odnawiane. Przedstawiona metoda wykorzystuje algorytm faktoryzacji, zaproponowana metodę $\pi$ oraz symulacje komputerowa. Na podstawie algorytmu faktoryzacji wyznaczany jest wzór do doktadnego obliczania niezawodności sieci jako prawdopodobieństwa połaczenia między wybranym zbiorem $K$ węzłów $\left(R_{N(K)}\right)$. Obliczana $w$ ten sposób niezawodność dotyczy przypadków gdy tylko połaczenia moga się uszkadzać i nie sa odnawiane. W celu obliczania niezawodności sieci z odnawianymi połączeniami i węzłami wprowadzono quasi uszkodzenia połączeń, które występuja na skutek uszkodzeń węzłów do nich przyległych - metoda $\pi$. Opracowana metoda pozwala uwzględnić odnawianie wszystkich elementów sieci po uszkodzeniu jak również możliwość wyboru zbioru węzłów $\left(N_{f}\right)$, które moga się niezależnie uszkadzać. Ponadto rozkłady prawdopodobieństwa czasu pracy do uszkodzenia dowolnie określonych zbiorów węzłów i połączeń mogą być różne. Do zaproponowanej metody opracowano symulacyjny model obliczeniowy, który umożliwia wyznaczenie niezawodności sieci $\left(R_{N(K)}(t)\right)$ z odnawianymi połaczeniami $i$ węzłami. Zgodnie z opracowanym modelem wykonano przykładowe obliczenia numeryczne i przedstawiono ich wyniki.
\end{abstract}

Stowa kluczowe: niezawodność sieci, algorytm faktoryzacji, uszkadzajace się połaczenia, uszkadzające się węzty, naprawialne elementy, metoda $\pi$, symulacja.

\section{Introduction}

Attempts to solve the network reliability issue have been made for years. The problem is important due to growing requirements in terms of reliable operation of various networks whose reliability is considered already at the design stage $[8,23]$. Computer, communication, gas, water supply, power and other networks are still expanding and becoming increasingly complex. Determination of the reliability of such networks is complicated and in many cases is a NP-hard problem $[1,2,20]$. The solutions suggested in the literature most often relate to a determination of the reliability of undirected networks due to their coherence and structure of links [22] or due to their effective distribution $[6,28]$. There are also attempts to account for both aspects in the reliability evaluation [18].

Three kinds of accurate computations exist for the network reliability: exact [13], approximate and boundary values [5,10]. Since Moskovitz [14] used it as an accurate method of network reliability determination due to its coherence, the factoring algorithm has very often been used, investigated and modified [17, 21]. The net- work model in the factoring algorithm is an undirected graph, and the reliability measure is the probability of connectedness among the specified set of nodes $-K$-terminal network reliability [7, 27]. The reliability is determined by a reduction of the graph representing the network with the assumption that the network nodes are perfectly reliable $[3,4]$. The reliability determination of networks with failing links and nodes was also considered and the proposed computation methods were presented in $[11,24,25]$. As network reduction is significantly time-consuming, there was a search for quicker and more effective methods [12]. The following can be used for these purposes: series-parallel, polygon-to-chain, delta-to-star, degree-1 and degree- 2 reductions, and also other methods [9, 26$]$. The formula obtained as a result of reduction allows computing a specified measure of network reliability for the chosen time. Practical applications of the factoring algorithm mainly regard real gas and water supply networks $[15,18]$ as well as computer networks [23].

$\left(^{*}\right)$ Tekst artykułu w polskiej wersji językowej dostępny w elektronicznym wydaniu kwartalnika na stronie www.ein.org.pl 
However, the reliability computed in this manner does not take into account the repair of failing network elements. The elements of real networks such as pipelines, telecommunication lines etc. are always repaired after failure. For the network reliability determination model to better reflect the reality, the repair of elements should be taken into account.

This paper presents the method of network reliability determination as the probability of connectedness among the specified set of nodes ( $K$-terminal network reliability) taking into account the repair of failing links and nodes. The failures and repairs of nodes were implemented according to the proposed $\pi$ method. The proposed model of reliability computation uses the classic factoring algorithm, the $\pi$ method and the simulation method suitably adapted to them. The reliability computation for networks with repairable elements comprises two stages. In stage I, which is based on classic factoring algorithm, the formula is obtained for accurate computation of reliability of a network without repair of the elements. In stage II, the formula and the $\pi$ method are used in the simulation procedure wherein the network reliability is determined when the nodes are repaired after failure.

\section{Notation and assumptions}

$G=(V, E)$-undirected graph which represents an undirected network,

$V=\left(v_{1}, v_{2}, \ldots, v_{n}\right)-$ set of vertices in a graph representing nodes in a network,

$E=\left(e_{1}, e_{2}, \ldots, e_{m}\right)-$ set of edges in a graph representing links in a network,

$v_{j}-$ vertex in a graph and node in a network, $v_{j} \in V$,

$e_{i}$ - edge in a graph and link in a network, $e_{i} \in E$,

$n$ - number of nodes in a network, $n=|V|$,

$N_{f}-$ set of nodes which can fail, $n_{f} \subseteq V$,

$m$ - number of links in a network, $\mathrm{m}=|E|$,

$K$ - specified set of vertices in a graph (nodes in a network) which should be connected in order to guarantee the network's operating state,

$G_{K}-$ graph with specified set $K \subseteq V$,

$x_{i}(t)$ - state of link $e_{i}$ at time $t$ expressed in a binary manner, $x_{i} \in\{0,1\}$,

$s e_{i}(t)$ - state of link $e_{i}$ at time $t$ expressed in a numerical manner, $\mathrm{s}_{i} \in\{1,0,-1,-2\}$,

$p_{i}=\operatorname{Pr}\left(x_{i}=1\right)-$ probability that link $e_{i}$ is in an operating state,

$q_{i}=1-p_{i}=\operatorname{Pr}\left(x_{i}=0\right)-$ probability that link $e_{i}$ is in a failure state,

$R_{N(K)}=R\left(G_{K}\right)$ - network reliability - probability of connectedness among the specified set $K$ of nodes ( $K$-terminal network reliability),

$A M$ - adjacency matrix of a network,

$X(t)=\left(x_{1}(t), x_{2}(t), \ldots, x_{m}(t)\right)-$ set of all links' states at time $t$,

$\operatorname{Se}(t)=\left(s e_{1}(t), s e_{2}(t), \ldots, s e_{m}(t)\right)-$ set of all links' states at time $t$ expressed in a numerical manner,

$\Phi(t)=R_{N(K)}(X(t))$ - function determining in a binary manner the network state at time t, $\Phi(t) \in\{0,1\}$,

$T_{h}$ - simulation time horizon,

$t_{e}$ - time of event,

$t_{f i j}$ - time when the $j$ th failure of link $e_{i}$ occurs,

$t_{r i j}$ - time when the $j t h$ repair of link $e_{i}$ ends,

$t_{s f}$ - time when in sth simulation a network's failure state occurs,

$s_{\max }-$ number of simulation repetitions,

$s_{f}(t)$ - number of simulations which until time $t$ ended with occurrence of the network's failure state,

$R_{N(K)}(t)$ - reliability of a network with links and nodes repairable after failure.

The following assumptions were made in order to determine the network reliability using the proposed method:

i Model of network is an undirected stochastic graph. ii The measure of network reliability is the probability that all nodes from specified set $K$ are connected - $K$-terminal network reliability.

iii All links $e_{i}$ in the network can fail statistically independently of each other with known probability $q_{i}=1-p_{i}$, and the distribution of failure time of each is known.

iv To obtain the formula for computation of network reliability $R_{N(K)}$, it is assumed that the nodes are perfectly reliable: $p_{v i}=1$, and the links are unrepairable.

$\mathrm{v} \quad$ When determining the reliability $R_{N(K)}(t)$ of a network with failing and repairable elements, all the links and nodes can fail statistically independently of each other with known probabilities, and the distribution of failure time of each is known.

vi A failure of a node in the network causes a quasi-failure of all links adjacent to the failed node.

vii Each network link $e_{i}$ and node $v_{j}$ can be in only one of two states: operating or failure.

viii Repair of each element results in restoration of its original reliability.

\section{Determination of reliability of a network with perfect nodes and unrepairable links}

The goal of stage I of the analysis is to obtain the formula for computation of reliability of a network with perfect nodes and unrepairable links. The factoring algorithm was used for this purpose. The formula $R_{N(K)}$ is obtained by reduction of the graph representing the network [16, 27]. The reduction process is based on a well-known principle of contracting and deleting of links which is recursively applied for all edges $e_{\mathrm{i}}$ in graph $G$.

Examples of reduction for specified sets $K$ are shown in Figure 1 (a: $|K|=|V|$, b: $\left.|K|=2:\left\{v_{1}, v_{2}\right\}\right)$.
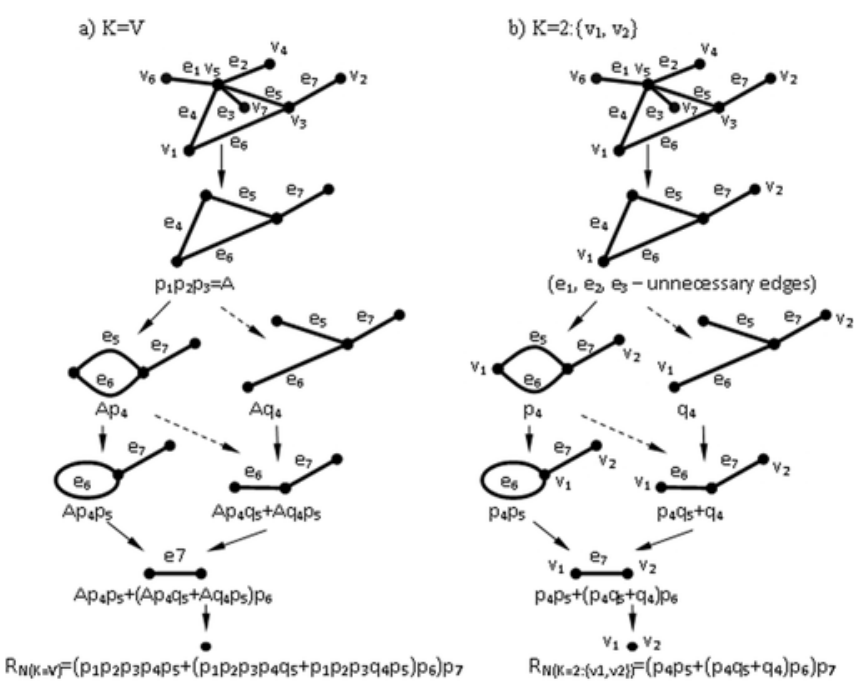

Fig. 1. Examples of reduction according to the factoring algorithm

\section{Reliability of a network with imperfect and repairable links and nodes $-\pi$ method}

In stage II of the analysis we present the $\pi$ method which takes into account the failures and repairs of links and nodes in the network.

Because, according to assumption vii, each link $e_{i}$ can be only in one of two states, it was assumed that this state will be expressed in a 
binary manner and denoted $x_{i}(t)$. As a result of failures and repairs, the values $x_{i}(t)$ can change in time as follows:

$$
x_{i}(t)=\left\{\begin{array}{l}
1-\text { link } e_{i} \text { is in anoperating state at timet } \\
0-\text { link } e_{i} \text { is in a failure state at timet }
\end{array}\right.
$$

and the set of states of all links in the network at any time $t$ is written as:

$$
X(t)=\left(x_{1}(t), x_{2}(t), \ldots, x_{m}(t)\right)
$$

The following substitution for probability values $p_{i}$ and $q_{i}$ are made in formulas for network reliability $\left(R_{N(K)}\right)$ obtained according to the factoring algorithm:

$$
\left\{\begin{array}{l}
p_{i}=x_{i}(t) \\
q_{i}=1-x_{i}(t)
\end{array}\right.
$$

Now, it can be noticed that after using formulas (1) - (3), the value of function $\Phi(t)=R_{N(K)}(X(t))$ in each case determines the network state in a binary manner due to the fact that the connectedness of nodes from set $K: 1-K$ nodes are connected, $0-K$ nodes are not connected, which will be written as:

$$
\Phi(t)=R_{N(K)}(X(t))=\left\{\begin{array}{l}
1-\text { operating state of network at timet } \\
0-\text { failure state of network at timet }
\end{array}\right.
$$

It is an easy method for determining the network state at any time $t$ for each possible case $X(t)$ resulting from combination of states $x_{i}(t)$ of network links.

As each link $e_{i}$ connects two nodes located on its ends (these nodes are adjacent to link $e_{i}$ ), the adjacency matrix $(A M)$ for any network can be written in the following form:

$$
A M=\left[\begin{array}{ccc}
a_{i, j} & \ldots & a_{i, n} \\
\vdots & \ddots & \vdots \\
a_{m, j} & \ldots & a_{m, n}
\end{array}\right] ; \quad j=1,2, \ldots, m
$$

$$
a_{i, j}=\left\{\begin{array}{l}
1-\text { if node } v_{j} \text { is one of two nodes adjacent tolink } e_{i} \\
0-\text { if node } v_{j} \text { isn't one of two nodes adjacent tolink } e_{i}
\end{array}\right.
$$

Matrix $A M$ will be used during calculation process to fastest finding the numbers of links which are in a failure state as a result of failure of nodes.

Analysing the structures of links in various networks, it is easy to notice that each link $e_{i}$ which is adjacent to the failed node cannot be used to connect the specified set $K$ of nodes. According to assumption vi, such a state is called a quasi-failure of the link.

If nodes $v_{k}$ and $v_{l}$ are adjacent to link $e_{i}$, possible cases of failure and quasi-failures of link $e_{i}$ are presented in Figure 2.

The cases presented in Figure 2 cause:

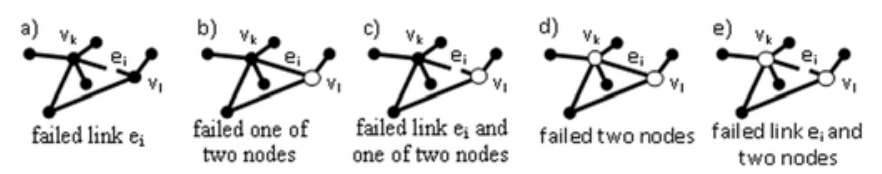

Fig. 2. Possible cases that caused a failure state and quasi-failures of link $e_{i}$
$-2 \mathrm{a}$ : failure of link $e_{i}$,

- 2b: quasi-failure of link $e_{i}$,

- 2c: failure and simultaneously quasi-failure of link $e_{i}$,

$-2 \mathrm{~d}$ : double quasi-failure of link $e_{i}$,

- 2e: failure and simultaneously double quasi-failure of link $e_{i}$.

Each kind of link's failure is assumed in calculations as a failure state of that link.

The numerical value $s e_{i}(t)$ which describes the link's state was introduced in order to allow for determining the number of failures at time $t$ which cause the failure state of the link. If at time $t$ the link $e_{i}$ is in operating state, $\operatorname{se}_{i}(t)=1$. Now, it was assumed that as a result of events, failures and repairs of link $e_{i}$ and nodes $v_{k}$ and $v_{l}$ occurring at time $t_{e}$, values $s e_{i}(t)$ of link $e_{i}$ and other links adjacent to nodes $v_{k}$ and $v_{l}$ will change as follows:

- if link $e_{i}$ at time $t_{e}$ changes into failure state:

$$
s e_{i}\left(t>t_{e}\right)=s e_{i}\left(t_{e}\right)-1
$$

- if node $v_{k}$ at time $t_{e}$ changes into failure state:

$$
\forall i\left(i \in(1, \ldots, m) \wedge\left(A M\left(a_{i, j=k}\right)=1\right) \Rightarrow s e_{i}\left(t>t_{e}\right)=s e_{i}\left(t_{e}\right)-1\right)
$$

- if node $v_{l}$ at time $t_{e}$ changes into failure state:

$$
\forall i\left(i \in(1, \ldots, m) \wedge\left(A M\left(a_{i, j=l}\right)=1\right) \Rightarrow s e_{i}\left(t>t_{e}\right)=s e_{i}\left(t_{e}\right)-1\right)
$$

- if link $e_{i}$ at time $t_{e}$ changes into operating state:

$$
s e_{i}\left(t>t_{e}\right)=s e_{i}\left(t_{e}\right)+1
$$

- if node $v_{k}$ at time $t_{e}$ changes into operating state:

$$
\forall i\left(i \in(1, \ldots, m) \wedge\left(A M\left(a_{i, j=k}\right)=1\right) \Rightarrow s e_{i}\left(t>t_{e}\right)=s e_{i}\left(t_{e}\right)+1\right)
$$

- if node $v_{l}$ at time $t_{e}$ changes into operating state:

$$
\forall i\left(i \in(1, \ldots, m) \wedge\left(A M\left(a_{i, j=l}\right)=1\right) \Rightarrow s e_{i}\left(t>t_{e}\right)=s e_{i}\left(t_{e}\right)+1\right)
$$

hence, from formulas (7) - (12) we obtain the set of possible values $s e_{i}(t)$ for each link:

$$
s e_{i}(t)=\left\{\begin{array}{c}
1-\text { operating state of link } e_{i} \text { and both nodes } v_{k}, v_{l} \\
0-\text { failure state of link } e_{i} \text { or node } v_{k} \text { or nodev } v_{l} \\
-1-\text { failure state of link } e_{i} \text { and oneof two nodes } v_{k}, v_{l} \text { or } \\
\text { operating state of link } e_{i} \text { and failurestateof both nodes } v_{k}, v_{l} \\
-2-\text { failure state of link } e_{i} \text { and bothnodes } v_{k}, v_{l}
\end{array}\right\}
$$

The set of values $s e_{i}(t)$ for all links in the network will be written as:

$$
S e(t)=\left(s e_{1}(t), s e_{2}(t), \ldots, s e_{m}(t)\right)
$$


Because each type of link failure is assumed in calculations as its failure state, the state of link $x_{i}(t)$ can be expressed in a binary manner, rewriting the formula (1) in the following form:

$$
x_{i}(t)=\left\{\begin{array}{l}
1-\text { if } \operatorname{se}_{i}(t)=1 ; \text { operating state of link } e_{i} \\
0-\text { if } s e_{i}(t)<1 ; \text { failure state of link } e_{i}
\end{array}\right.
$$

This proposed method of accounting for failures and repairs of links and nodes in the network (7) - (15) is called the $\pi$ method (3.14) because:

- the state of each link depends on $\mathbf{3}$ elements: the link and two nodes adjacent to this link,

- there is only $\mathbf{1}$ possibility when the link is in an operating state: the link and both nodes adjacent to this link are in an operating state,

- the state of each link is quantified by a maximum 4 values: $s e_{i}(t) \in\{1,0,-1,-2\}$.

In this way, using the $\pi$ method we determine the state of link $e_{i}$ taking into account failures of the link itself and failures of adjacent nodes.

Using formula (15) we now also obtain the set of states $X(t)$, and from formula (4) we can calculate function $\Phi(t)$. Hence, it is possible to determine the state of the whole network due to connections of nodes from set $K$, at imperfect and repairable links and nodes.

\section{Implementation of the $\pi$ method-simulation model for estimation network reliability}

The simulation method is implemented according to the diagram which for the network from Figure 1a is exemplary presented in Figure 3. Successive values of failure times and repair times are sampled independently for each link $e_{i}$ and node $v_{j}$ (we used the method of inverse cumulative distribution function) [19]. These values are summed, thus making successive values of times $t_{f i j}$ and $t_{r i j}$. The process continues until the simulation time horizon $\left(T_{h}\right)$ is reached, or until the network is in a failure state $(\Phi(t)=0)$. The nodes failures are accounted for by means of quasi-failures of links according to the $\pi$ method.

The method of results analysis by using: $R_{N(K)}$ formula, matrix $A M$ and $\pi$ method is presented in Table 1 .

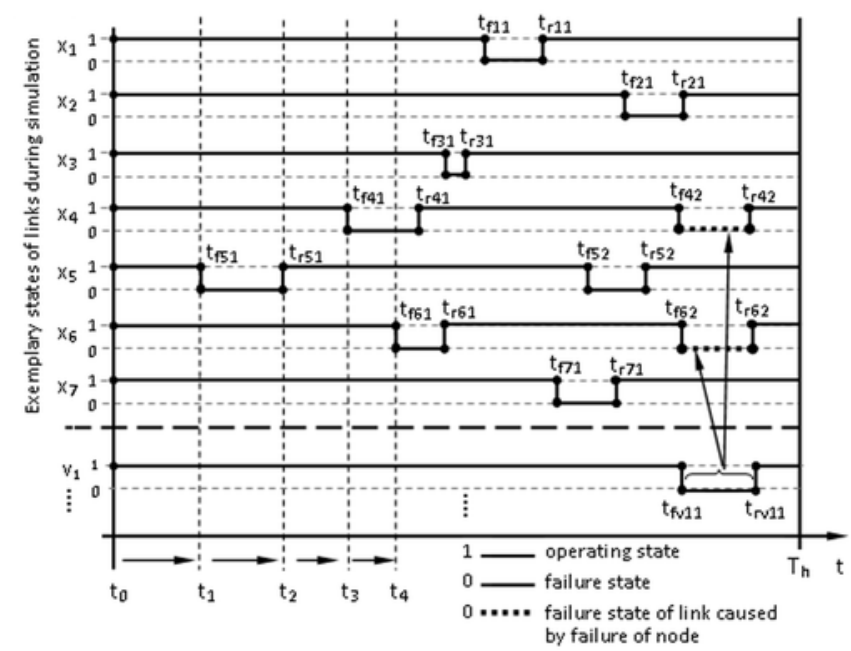

Fig. 3. Exemplary states of $x_{i}(t)$ of network links from Fig. 1a) during simulation
The presented method of sampling the time of events (failure and repair completion of the links and nodes) and of their analysis is applied in each simulation, which is repeated a specified number of times $\left(s_{\max }\right)$. The obtained values of times $t_{s f}$ from all the simulations are then used to compute the reliability of a network with repairable links and nodes according to the formula:

$$
R_{N(K)}(t)=1-\frac{s_{f}(t)}{s_{\max }}
$$

\begin{tabular}{|c|c|c|c|c|}
\hline No. & $t$ & $X(t)$ & $R_{N(K=V)}$ & $\Phi(t)=R_{N(K=V)}(X(t))$ \\
\hline 1 & $t_{0}$ & $X\left(t_{0}\right)=(1,1,1,1,1,1,1)$ & \multirow{5}{*}{$\begin{array}{c}\left(p_{1} p_{2} p_{3} p_{4} p_{5}+\left[p_{1} p_{2} p_{3} p_{4} q_{5}+\right.\right. \\
\left.\left.p_{1} p_{2} p_{3} q_{4} p_{5}\right] p_{6}\right) p_{7} \\
\text { after applying }(3): \\
\left(x_{1}(t) x_{2}(t) x_{3}(t) x_{4}(t) x_{5}(t)+\right. \\
{\left[x_{1}(t) x_{2}(t) x_{3}(t) x_{4}(t)\left(1-x_{5}(t)\right)+\right.} \\
\left.\left.x_{1}(t) x_{2}(t) x_{3}(t)\left(1-x_{4}(t)\right) x_{5}(t)\right] x_{6}(t)\right) x_{7}(t)\end{array}$} & 1 - operating state \\
\hline 2 & $t_{1}$ & $X\left(t_{1}\right)=(1,1,1,1,0,1,1)$ & & 1 - operating state \\
\hline 3 & $t_{2}$ & $X\left(t_{2}\right)=(1,1,1,1,1,1,1)$ & & 1 - operating state \\
\hline 4 & $t_{3}$ & $X\left(t_{3}\right)=(1,1,1,0,1,1,1)$ & & 1 - operating state \\
\hline 5 & $t_{4}$ & $X\left(t_{4}\right)=(1,1,1,0,1,0,1)$ & & $\begin{array}{l}0 \text { - failure state } \\
\text { of network: } t_{4}=t_{s f}\end{array}$ \\
\hline
\end{tabular}

Table 1. Method of result analysis during simulation for link states from Figure 3

The simulation procedure was written as a computer program using the Matlab package. The program makes it possible to compute various measures of network reliability for the following cases:

- perfectly reliable nodes $\left(N_{f}=\varnothing\right)$,

- failures and repairs of all network nodes $\left(N_{f}=V\right)$,

- failures and repairs of a chosen set of nodes $\left(\left|N_{f}\right|<|V|\right)$.

In addition, any subsets of failing links and nodes can have different probability distributions of failure time and different values of repair rate.

\section{Example and results of application of the method}

The developed method was applied to compute the reliability of network presented in Figure 4. The model of this network in the form of an undirected graph consists of 36 links and 34 nodes.

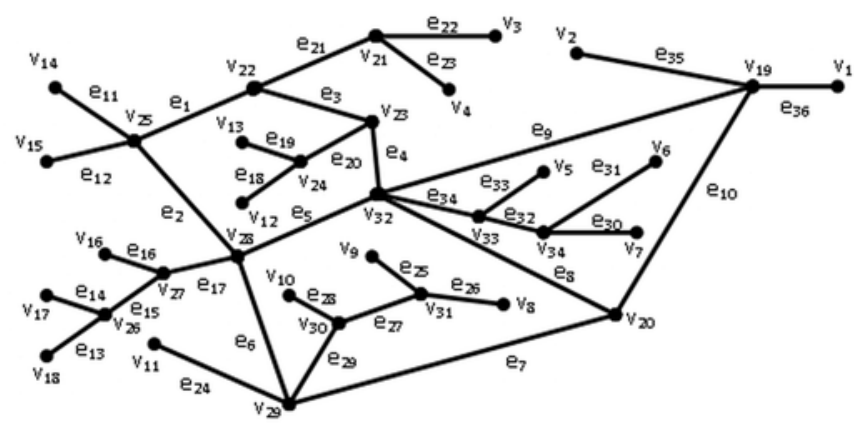

Fig. 4. Structure of the analysed network

Reductions were made for the analysed network according to the method presented in stage I, and the formulas were obtained to

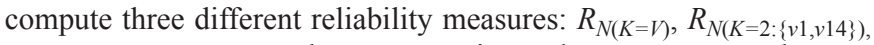
$R_{N(K=18:\{v 1-v 18\}) \text {. Formulas are extensive and are not presented. }}$

Obtained formulas were used in the simulation computations. The probability distributions of failure time and of repair of nodes and links, along with the parameters used in simulations, are presented in Table 2. In all cases, the exponential distribution of repair probability and $\mu=10$ [1/t.u.] (t.u. - time unit) was assumed for nodes $v_{j} \in N_{f}$ and links $e_{i}$. The results of the computations for all cases from Table 3 are presented in Figures 5 and 6. 
Table 2. Probability distributions and parameters used in the simulations

\begin{tabular}{|c|c|c|c|}
\hline Network reliability measure & Set of nodes which can fail $N_{f}$ & $\begin{array}{l}\text { Probability distribution of failure } \\
\text { time for nodes } v_{j} \in N_{f}\end{array}$ & $\begin{array}{l}\text { Probability distribution of failure } \\
\text { time for links } e_{i} \in E\end{array}$ \\
\hline $\begin{array}{c}\text { I: } \\
\mathrm{R}_{\mathrm{N}(\mathrm{K}=18):\{\mathrm{v} 1-\mathrm{v} 18\}}\end{array}$ & $\begin{array}{c}\text { 1) } N_{f}=\varnothing \text { : } \\
\text { all nodes perfectly reliable }\end{array}$ & - & $\begin{array}{c}\text { Exponential: } \\
\lambda=3 \cdot 10^{-4}[1 / \text { t.u. }]\end{array}$ \\
\hline \multirow{3}{*}{$\begin{array}{c}\text { II: } \\
\mathrm{R}_{\mathrm{N}(\mathrm{K}=18):\{\mathrm{v} 1-\mathrm{v} 18\}}\end{array}$} & 1) $N_{f}=\varnothing$ & - & \multirow{3}{*}{$\begin{array}{c}\text { Normal: } \\
m=80 \text { [t.u.]; } \sigma=25 \text { [t.u.] }\end{array}$} \\
\hline & 2) $N_{f}=16:\left\{v_{19}, \ldots, v_{34}\right\}$ & $\begin{array}{c}\text { Weibull: } \\
\alpha=1.9 ; \beta=150 \text { [t.u.] }\end{array}$ & \\
\hline & 3) $N_{f}=16:\left\{v_{19}, \ldots, v_{34}\right\}$ & $\begin{array}{c}\text { Weibull: } \\
\alpha=1.9 ; \beta=100 \text { [t.u.] }\end{array}$ & \\
\hline \multirow{4}{*}{$\begin{array}{c}\text { III: } \\
\mathrm{R}_{\mathrm{N}(\mathrm{K}=\mathrm{V})}\end{array}$} & 1) $N_{f}=\varnothing$ & - & \multirow{4}{*}{$\begin{array}{c}\text { Weibull: } \\
\alpha=1.9 ; \beta=150 \text { [t.u.] }\end{array}$} \\
\hline & 2) $N_{f}=16:\left\{v_{19}, \ldots, v_{34}\right\}$ & Weibull: & \\
\hline & 3) $N_{f}=V:\left\{v_{1}, \ldots, v_{34}\right\}$ & $\alpha=1.9 ; \beta=150$ [t.u.] & \\
\hline & 4) $N_{f}=V:\left\{v_{1}, \ldots, V_{34}\right\}$ & $\begin{array}{c}\text { Weibull: } \\
\alpha=1.9 ; \beta=100 \text { [t.u.] }\end{array}$ & \\
\hline \multirow{5}{*}{$\begin{array}{c}\text { IV: } \\
\mathrm{R}_{\mathrm{N}(\mathrm{K}=2):\{\mathrm{v} 1, \mathrm{v} 14\}}\end{array}$} & 1) $N_{f}=\varnothing$ & - & \multirow{2}{*}{$\begin{array}{c}\text { Normal: } \\
m=80 \text { [t.u.]; } \sigma=25 \text { [t.u.] }\end{array}$} \\
\hline & 2) $\begin{array}{c}N_{f}=8:\left\{v_{19}, v_{20}, v_{22}, v_{23}\right. \\
\left.v_{25}, v_{28}, v_{29}, v_{32}\right\}\end{array}$ & $\begin{array}{c}\text { Weibull: } \\
\alpha=1.9 ; \beta=150 \text { [t.u.] }\end{array}$ & \\
\hline & 3) $N_{f}=\varnothing$ & - & \multirow{2}{*}{$\begin{array}{c}\text { Weibull: } \\
\alpha=1.9 ; \beta=150 \text { [t.u.] }\end{array}$} \\
\hline & 4) $\begin{array}{c}N_{f}=8:\left\{v_{19}, v_{20}, v_{22}, v_{23}\right. \\
\left.v_{25}, v_{28}, v_{29}, v_{32}\right\}\end{array}$ & $\begin{array}{c}\text { Weibull: } \\
\alpha=1.9 ; \beta=150 \text { [t.u.] }\end{array}$ & \\
\hline & 5) $\begin{aligned} N_{f}=8: & \left\{v_{19}, v_{20}, v_{22}, v_{23},\right. \\
& \left.v_{25}, v_{28}, v_{29}, v_{32}\right\}\end{aligned}$ & $\begin{array}{c}\text { Weibull: } \\
\alpha=1.9 ; \beta=100 \text { [t.u.] }\end{array}$ & $\begin{array}{c}\text { links } e_{11}, e_{36}-\text { Weibull: } \\
\alpha=1.9 ; \beta=100 \text { [t.u.], } \\
\text { other links - Normal: } \\
m=80 \text { [t.u.]; } \sigma=25 \text { [t.u.] }\end{array}$ \\
\hline
\end{tabular}

a)

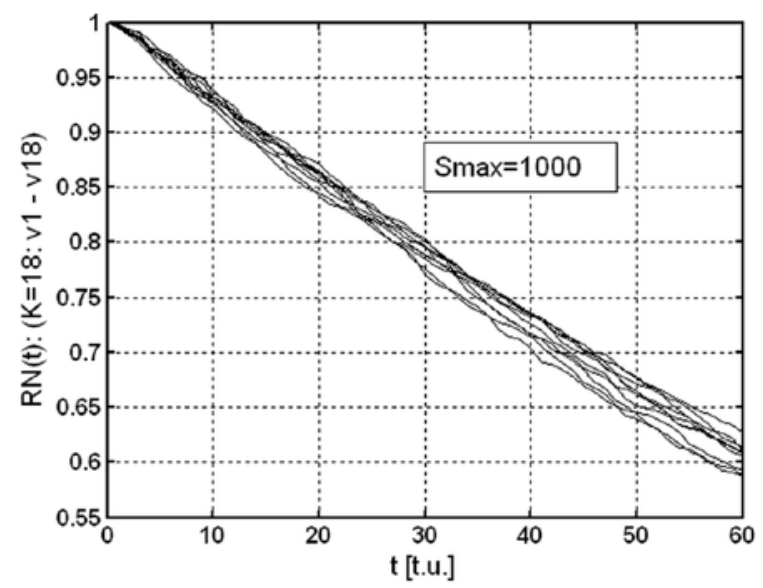

c)

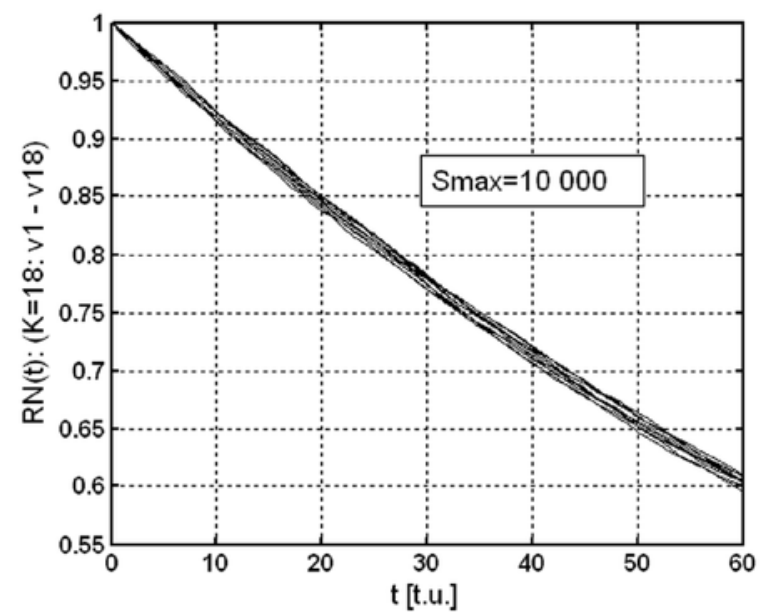

b)

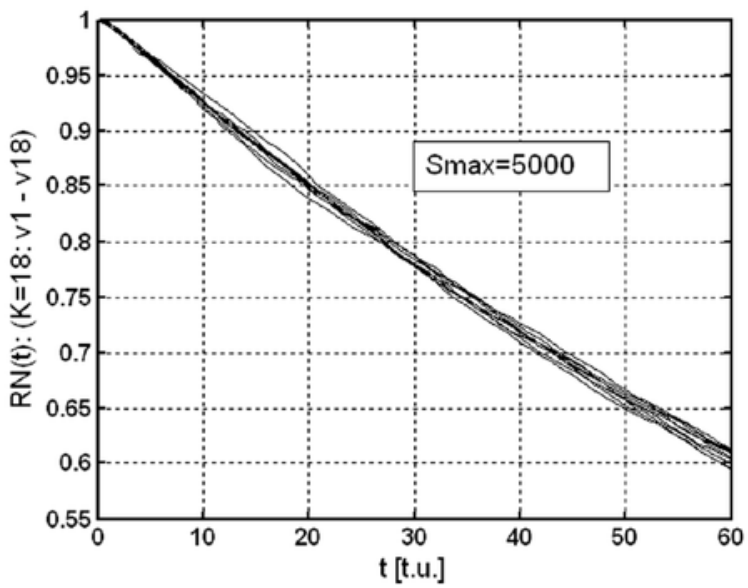

d)

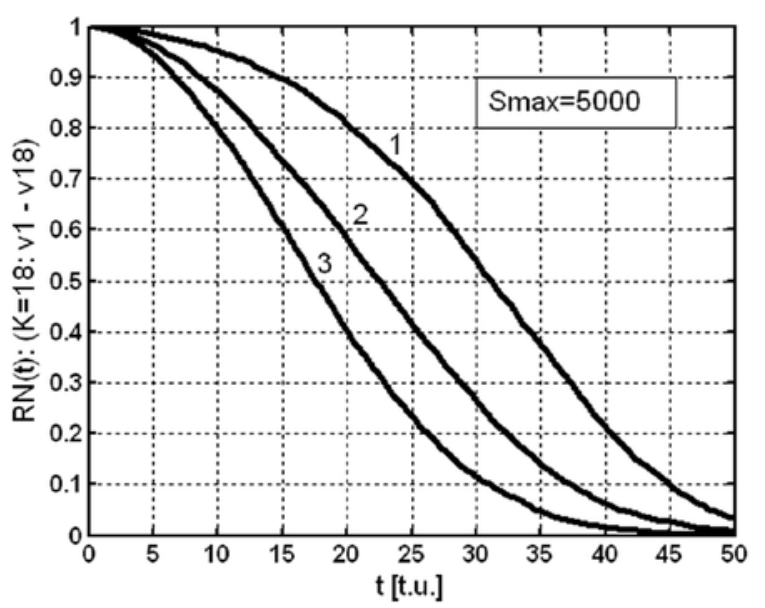

Fig. 5. Dispersion of results depending on the number of repetitions: a), b), c) - case I according to Table 2, and network reliability: d) - case II according to Table 2 


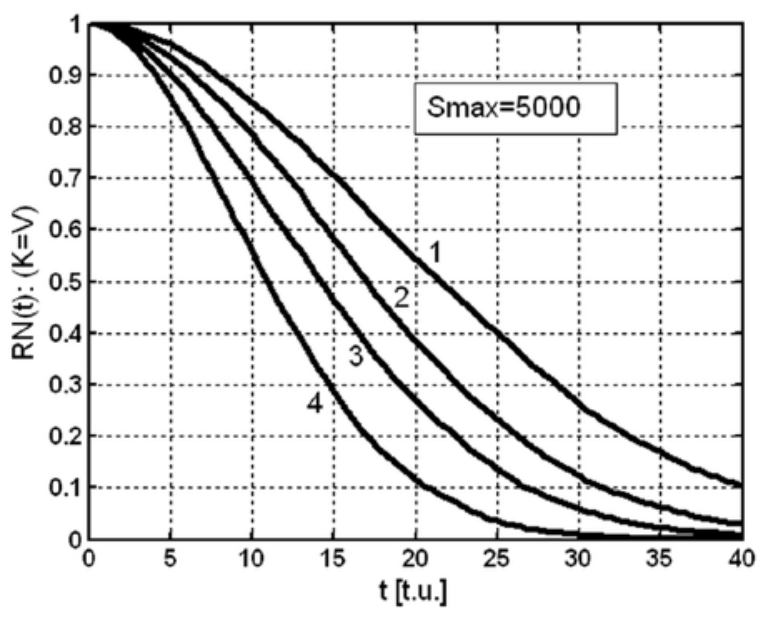

Fig. 6. Network reliability: a) -case

Figures $5 \mathrm{a}, 5 \mathrm{~b}$ and $5 \mathrm{c}$ present the dispersion of results from 10 simulations depending on the number of repetitions $\left(s_{\max }\right)$ of a single simulation. One can notice that the increase of the number of repetitions $s_{\max }$ from 1000 to 5000 significantly improves the convergence of results, but increasing $s_{\max }$ to 10000 does not result in a significant improvement. The average computation time increased from 0.9 [s] to 2.6 [s], and for $s_{\max }=10000$ to 4.9 [s]. The computations were performed on a standard $\mathrm{PC}$ with a $1.5[\mathrm{GHz}]$ processor and 2 [GB] RAM. Figure 5d presents the reliability of the analysed network $R_{N(K=18:\{\mathrm{v} 1-\mathrm{v} 18\})}(t)$ when the network nodes do not fail, and when the specified set of nodes $N_{f}$ fails - case II in Table 2.

Figure 6a presents network reliability $\mathrm{R}_{\mathrm{N}(\mathrm{K}=\mathrm{V})}(\mathrm{t})$ obtained for case III according to Table 2. Figure $6 \mathrm{~b}$ presents another measure of network reliability $\mathrm{R}_{\mathrm{N}(\mathrm{K}=2:\{\mathrm{v} 1, \mathrm{v} 14\})}(\mathrm{t})$, also obtained for various sets of failing nodes in the network and various probability distributions of failure time. In all cases, accounting for possible failures of a specified set of nodes or all nodes results in a reduced network reliability when compared to the situation with perfectly reliable nodes. For cases II, III and IV in Table 2, when the links and nodes failed, the calculation time at $\mathrm{s}_{\max }=5000$ was in the $5-20[\mathrm{~s}]$ range.

\section{Summary and critical discussion}

The developed computation method allows determination of the various reliability measures for networks with repairable elements. This method cab be used mainly for calculating structural reliability of real water and gas supply networks as well as logistics and different kind of telecommunications networks. Especially it can be useful for computer networks where links and nodes are completely different elements but both have strong influence on network reliability.

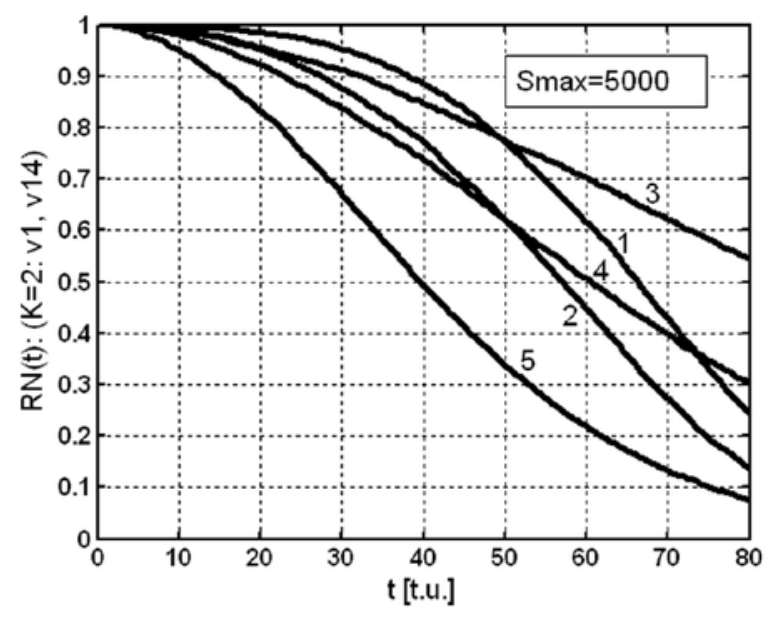

III, b) - case IV according to Table 2
The developed model can also be applied to compute the reliability of other complex technical systems with specified (known) reliability structures which contain repairable elements.

The proposed $\pi$ method allows for accounting for the failures of both links and nodes in the network by the introduction of quasifailures of links. After applying the $\pi$ method, the formulas obtained according to the factoring algorithm which account only for the failure of links allow for an easy determination of the state of the whole network when both links and nodes fail. In the developed simulation model it is possible to use various probability distributions of failure time for any subsets of links and subsets of nodes which can fail (imperfect nodes). The failing elements can also have different values of repair rate.

The results indicate that using the models with perfectly reliable nodes $\left(N_{f}=\varnothing\right)$ leads to overestimating the network reliability. Taking failures and repairs of nodes and links into account makes the model better reflect failures occurring in real networks. Hence, the presented model can be more useful in the analysis of practical cases, giving a more credible assessment of network reliability.

The inconvenience of the above method is the need to use the formulas obtained according to the factoring algorithm which, in the case of very complex network, are rather time-consuming to obtain. Further research can aim at searching for more effective network reduction methods and methods of obtaining formulas for sought network reliability measures $R_{N(K)}$, e.g. by development of computer algorithms or modification of the method and determination of the network reliability without the need to use them. Another interesting direction for future research can be a modification of the method for use in directed networks.

\section{References}

1. Ball M O. Complexity of network reliability computations. Networks 1980;10: 153-165, http://dx.doi.org/10.1002/net.3230100206.

2. Ball M O. Computational complexity of network reliability analysis: An overview. IEEE Transactions on Reliability 1986; 35 (3): 230-39, http://dx.doi.org/10.1109/TR.1986.4335422.

3. Beichelt F, Tittmann P. A generalized reduction method for the connectedness probability of stochastic networks. IEEE Transactions on Reliability 1991; 40 (2): 198-204, http://dx.doi.org/10.1109/24.87128.

4. Carlier J, Lucet C. A decomposition algorithm for network reliability evaluation. Discrete Applied Mathematics 1996; 65: 141-156, http:// dx.doi.org/10.1016/0166-218X(95)00032-M.

5. Gnedenko B, Ushakov I. Probabilistic reliability engineering, Falk J Ed., Wiley, New York, Chichester, Brisbane, Toronto, Singapore 1995: 340-377, http://dx.doi.org/10.1002/9780470172421.ch9.

6. Gu C, Wu J, Li F. Reliability-based distribution network pricing. IEEE Transactions on Power Systems 2012; 27 (3): 1646-1655, http:// dx.doi.org/10.1109/TPWRS.2012.2187686.

7. Hardy G, Lucet C, Limnios N. K-Terminal network reliability measures with binary decision diagrams. IEEE Transactions on Reliability 2007; 56 (3): 506-515, http://dx.doi.org/10.1109/TR.2007.898572. 
8. Jan R-H. Design of reliable networks. Computers \& Operations Research 1993; 20: 25-34, http://dx.doi.org/10.1016/03050548(93)90093-X.

9. Koide T, Shinmori S, Ishii H. Topological optimization with a network reliability constraint. Discrete Applied Mathematics 2001; 115: 135149, http://dx.doi.org/10.1016/S0166-218X(01)00221-9.

10. Krivoulets V G, Polesskii V P. Quasipacking bounds for network reliability. Information Processes 2001; 1 (2): $126-146$.

11. Lin M S, Chen D J, Horng M S. The reliability analysis of distributed computing systems with imperfect nodes. The Computer Journal 1999; 42 (2): 129-141, http://dx.doi.org/10.1093/comjnl/42.2.129.

12. Liu W Li J. An improved recursive decomposition algorithm for reliability evaluation of lifeline networks. Earthquake Engineering \& Engineering Vibration 2009; 8: 409-419, http://dx.doi.org/10.1007/s11803-009-8152-2.

13. Lucet C, Manouvrier J-F. Exact methods to compute network reliability, in Statistical and Probabilistic Models in Reliability, Ionescu D C and Limnios N, Eds. Birkhauser, Boston 1999: 279-294, http://dx.doi.org/10.1007/978-1-4612-1782-4_20.

14. Moskowitz F. The analysis of redundancy networks. AIEE Trans. (Commun. Electron.) 1958; 39: 627-632.

15. Natvig B, Morch H. An application of multistate reliability theory to an offshore gas pipeline network. International Journal of Reliability, Quality and Safety Engineering 2003; 10 (4): 361-381, http://dx.doi.org/10.1142/S0218539303001214.

16. Page L B, Perry J E. A practical implementation of the factoring theorem for network reliability. IEEE Transactions on Reliability 1988; 37 : 259-267, http://dx.doi.org/10.1109/24.3752.

17. Pilch R, Szybka J, Broniec Z. Determining of hot water-pipe exploitation time on the basis of limiting states. Eksploatacja i Niezawodnosc - Maintenance and Reliability 2012; 14 (3): 203-207.

18. Pilch R, Szybka J, Tuszynska A. Application of factoring and time-space simulation methods for assessment of the reliability of water-pipe networks. Eksploatacja i Niezawodnosc - Maintenance and Reliability 2014; 16 (2): 253-258.

19. Pilch R. A method for obtaining the required system reliability level by applying preventive maintenance. Simulation: Transactions of the Society for Modeling and Simulation International 2015; 91 (7): 615-624, http://dx.doi.org/10.1177/0037549715592274.

20. Provan J S. The complexity of reliability computations on planar and acyclic graphs. SIAM Journal on Computing 1986; 15 (3): 694-702, http://dx.doi.org/10.1137/0215050.

21. Ramirez-Marquez J E, Rocco C M. All-terminal network reliability optimization via probabilistic solution discovery. Reliability Engineering and System Safety 2008; 93: 1689-1697, http://dx.doi.org/10.1016/j.ress.2008.01.001.

22. Resende L. Implementation of a factoring algorithm for reliability evaluation of undirected networks. IEEE Transactions on Reliability 1988; 37 (5): 462-468, http://dx.doi.org/10.1109/24.9862.

23. Soi I M, Aggarwal K K. Reliability indices for topological design of computer communication networks, IEEE Transactions on Reliability 1981; 30: 438-443, http://dx.doi.org/10.1109/TR.1981.5221158.

24. Theologou O R, Carlier J G. Factoring and reductions for networks with imperfect vertices. IEEE Transactions on Reliability 1991; 40: 210217, http://dx.doi.org/10.1109/24.87131.

25. Torrieri D. Calculation of node-pair reliability in large networks with unreliable nodes, IEEE Transactions on Reliability 1994; 43: 375-82, http://dx.doi.org/10.1109/24.326428.

26. Wood R K. A factoring algorithm using polygon-to-chain reductions for computing K-terminal network reliability. Networks 1985; 15: 173190, http://dx.doi.org/10.1002/net.3230150204.

27. Wood R K. Factoring algorithms for computing K-terminal network reliability. IEEE Transactions on Reliability 1986; 35 (3): 269-278, http://dx.doi.org/10.1109/TR.1986.4335431.

28. Yannopoulos S, Spiliotis M. Water distribution system reliability based on minimum cut - set approach and the hydraulic availability. Water Resources Management 2013; 27: 1821-1836, http://dx.doi.org/10.1007/s11269-012-0163-5.

\section{Robert PILCH}

AGH University of Science and Technology Faculty of Mechanical Engineering and Robotics Department of Machine Design and Technology

Al. A. Mickiewicza 30, 30-059 Cracow, Poland E-mail: pilch@agh.edu.pl 